\title{
ЗАРУБІЖНИЙ ДОСВІД МОНІТОРИНГУ ЯКОСТІ ВИЩОЇ ОСВІТИ В ДОСДІДЖЕННЯХ ВІТЧИЗНЯНИХ НАУКОВЦІВ
}

У статті обьрунтовано важливість для сьогодення забезпечення якості освіти взагалі тавищої зокрема, представлено результати досліджень українських учених системи моніторингу якості вищої освіти в зарубіжних країнах у контексті трансформації суспільства та реформування украйнських закладів вищої освіти. Проаналізовано науковий доробок зарубіжних дослідників з проблем узагальнення досвіду освітнього моніторингу якості вищої освіти в різних типах навчальних закладів та діяльності спеціально створених міжнародних організацій $i$, насалперед, агентств із контролю якості освіти. Висвітлено діяльність різних інституц̧ій контролю за якістю освіти в закладах вищої освіти Украӥни. Доведено, що головною метою діяльності останніх є визначення оптимальних шляхів підвищення якості освітнього процесу та ухвалення відповідних управлінських рішень. Розкрито різні підходи до суті понять «інтернаціоналізація освіти», "якість освіти», "моніторинг», теоретичні, методологічні та організаційні аспекти моніторингу якості вищої освіти репрезентовані українськими та зарубіжними науковияли. Установлено, щзо в умовах інтернаціоналізациї освіти відбувається об'єднання підходів щзодо моніторингу якості освіти, яка визначаеться на внутрішньому рівні, на зовнішньому рівні, представлена національною акредитацією та міжнародною організацією зі стандартизацій; процедурою якісного аналізу інтернаціоналізації.

Визначено ключову роль моніторингу в підвищенні якості освіти. Доведено, щзо якість вищої освіти визнано пріоритетом розвитку сучасного інформаційного суспільства, головною стратегією освітнвої політики розвинених краӥн. Обьрунтовано, щяо моніторинг якості освіти, спрямований на забезпечення дотримання відповідних стандартів освіти в діяльності закладів освіти та надання суспільству освітніх послуг високої якості.

Ключові слова: моніторинг, якість освіти, вищза школа, освітній простір, дослідження, досвід, міжнародні стандарти, система державного управління якістю освіти.

Постановка проблеми. Реформування української вищої освіти відбувається в контексті європейських культурно-освітніх процесів, орієнтуючись на позитивні зміни та нові освітні орієнтири. Ураховуючи це, мета сучасної вищої школи включає в себе побудову конкурентоздатної економіки, яка базується на знаннях, підвищенні якості зайнятості населення та зміцненні соціальної єдності суспільства.

Одним із актуальних питань сьогодення є забезпечення якості освіти взагалі, а особливо вищої, та іï відповідність міжнародним стандартам. Це є стимулом до моніторингу якості національної системи освіти, яку визнала Рада Европи, i iï головним завданням є створення єдиного європейського освітнього простору. Ключову родь у моніторингу відіграє підвищення ефективності системи управдіння якістю освіти, а систематичність збору інформації є важдивим інструментом швидкого реагування на зміни внутрішнього і зовнішнього освітнього середовища. При цьому необхідно посилювати роль професіонала-експерта, який матиме значний досвід і достатньо часу для спостереження та оцінки різноманітних особливостей діяльності закладу освіти. А постійний моніторинг якості освітнього процесу, його змісту та результатів особливо необхідний в умовах реформування освіти в Україні задля введення сучасних освітніх стандартів.

*C) Завгородня Т. К.

بs 
Аналіз досліджень. У сучасних умовах проблема моніторингу якості освіти є предметом наукового дослідження в працях вітчизняних i зарубіжних учених. Зокрема, наукові пошуки українського науковця О. Локшиної присвячені становленню й розвитку моніторингу якості освіти в контексті світового виміру, визначенню сучасних підходів до організації досліджень 3 моніторингу якості освіти, характеристиці міжнародних моделей освітніх індикаторів. Т. Лукіна науково обгрунтувала українську систему державного управління якістю середньої освіти та запропонувала структуру моніторингових досліджень.

Наукові праці О. Ляшенко розкривають концептуальні засади моніторингу якості освіти, сутність категорій «якість освіти», «моніторинг», визначають стратегію якості основою освітньої політики країн світу та встановлюють управління якістю освіти як складник державного управдіння освітньою гадуззю. Сучасні підходи розвитку поняття якості освіти у світовому контексті представлено в наукових розвідках О. Овчарук, аналіз і характеристику міжнародних порівнядьних досліджень подано в працях І. Іванюк. Аналізу сутності понять «моніторинг», «якість освіти», з'ясуванню пріоритетних напрямів моніторингу якості інтернаціоналізаційної діяльності, характеристиці діяльності міжнародних організацій і агентств 3 контролю за якістю освіти, зокрема Агенства із забезпечення якості вищої освіти у Великій Британії, присвячено наукові публікації Ж. Чернякової.

Вивченню досліджуваного феномену приділяють увагу й зарубіжні дослідники: британський науковець Р. Барнет (розкрив підходи до визначення якості вищої освіти); П. Якобссон (виокремив критерії до визначення якості вищої освіти); А. Харві (виділив та обгрунтував підходи до встановлення якості вищої освіти) та інші.

Мета статті - на основі аналізу досліджень українських учених узагальнити досвід зарубіжних країн з проблем моніторингу якості вищої освіти.

Виклад основного матеріалу. На сучасному етапі необхідність модернізації освітніх систем різних країн світу зумовлена багатьма факторами, серед яких: 1) вимоги формування професійно підготовлених фахівців, які здатні забезпечити політичну незалежність, економічний і соціальний розвиток та конкурентоспроможність держави; 2) визнання якості вищої освіти пріоритетом розвитку сучасного інформаційного суспільства, головною стратегією освітньої політики розвинених країн, зокрема Великої Британії, Нідерландів, Польщі, США тощо.

В умовах розбудови української системи освіти провідне місце також посідає проблема якості освіти, іiі моніторингу, тому що, як зазначає Ж. Чернякова, вона визначає «суспільний розвиток держави в контексті евроінтеграційних процесів і конкурентоспроможність на европейському та глобальному ринку праці» [6, с. 196]. Автор, аналізуючи різноманітні документи (Національна доктрина розвитку освіти (2002), Наказ МОНмолодьспорту України «Про затвердження Плану дій щодо забезпечення якості вищої освіти в Україні та їі інтеграції в європейське світове освітнє співтовариство на період до 2010 року» (2007), Постанови «Про затвердження порядку проведення моніторингу якості освіти» (2011)), виокремила механізм організації та проведення моніторингу якості різних складових системи освіти України, установила стратегічні напрями діяльності щодо забезпеченні якості вищої освіти.

Значне місце в Законі України «Про вищу освіту» відводиться одній 3 найважливіших проблем сучасності - проблемі якості освіти взагалі й вищої зокрема. Зокрема, у першій статті цього документу серед основних термінів дається визначення таким: «якість вищої освіти» та «якість освітньої діяльності». Суть першого визначення відображає рівень здобуття особою знань, умінь, навичок, інших компетентностей, що відображає ії компетентність відповідно до стандартів вищої освіти. Водночас якість освітньої діяльності визначається, як «рівень організації освітнього процесу у вищому навчальному закладі, що відповідае стандартам вищої освіти, забезпечуе здобуття особами якісної вищої освіти та сприяе створенню нових знань» $[1$, с. 1]. Не важко

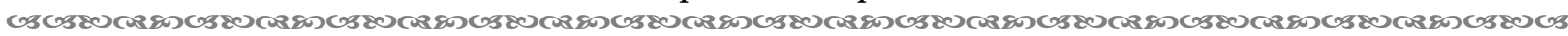
166 
помітити, що ці два терміни взаємопов'язані: якість освітньої діяльності у ЗВО впливає на якість вищої освіти. Водночас остання коректуе освітню діяльність закладу й кожного викладача зокрема, тому, висвітлюючи обрану проблему, ми робимо аналіз наукових розвідок дослідників різних країн, присвячених якості вищої освіти (поняття компетентностей, набутих особою в процесі навчання за певною освітньо-професійною, освітньо-науковою програмою; результатів навчання - сукупності знань, умінь і навичок, які можна ідентифікувати, кількісно оцінити та виміряти тощо); а також результати якості освітньої діяльності (рівень організації освітнього процесу у ЗВО, що відповідае стандартам вищої освіти й забезпечуе здобуття особою якісної вищої освіти). Також у 5 розділі цього документу (ст. 16) регламентуеться забезпечення якості вищої освіти.

У зв'язку 3 тим, що головною метою моніторингу навчальних досягнень є поліпшення стану саме підготовки студентів у 3ВО, при Київському політехнічному інституті в 2005 р. створено Інститут моніторингу якості освіти, завданнями якого визнано створення технологій моніторингу якості вищої освіти, організація та проведення систематичного моніторингу якості підготовки фахівців та формування рекомендацій щодо удосконалення освітнього процесу, проведення систематичного ректорського контролю залишкових знань, інформаційна підтримка самоаналізу діяльності з питань якості освіти при підготовці до процедур атестації та акредитації. У НПУ ім. М. П. Драгоманова 3 того ж року введено моніторинг якості освіти 3 метою постійного, систематичного збору відомостей про освітній процес задля визначення оптимальних шляхів підвищення його якості та ухвалення відповідних управлінських рішень. Науково-методичний центр кредитно-модульного навчання та моніторингу якості освіти (Київський університет ім. Б. Грінченка, 2008 р.) здійснює анадіз даних 3 організації та проведення контролю знань студентів, заліково-екзаменаційних сесій, державної атестації, ректорських контрольних робіт, анкетування студентів тощо.

Відомо, що основним засобом вивчення навчальних досягнень студентів ЗВО є моніторинг, система інструментарію якого здатна оцінити ефективність освітнього процесу, передбачити подальші кроки до його підвищення, вивчення та врахування досвіду тих країн, де така система діє на високому рівні. Зокрема, створені у Великобританії міжнародні організації з контролю якості освіти розробили основні напрями оцінки якості міжнародних освітніх програм транснаціонадьної освіти, а також програми в різних галузях, що відповідає сучасним вимогам ринку праці [6, с. 198]. Заслуговуе на увагу й висновок автора не тільки про розробку теоретичних положень досліджуваної проблеми, але й практичне значення, а саме: розробка спеціальних інструментаріїв та проведення особливих заходів щодо контродю якості освіти. Заслугою автора є й узагальнення в таблиці змісту діяльності окремих національних організацій або агентств 3 контролю якості освіти [там само].

Значна кількість наукових пошуків присвячена визначенню сутності понять «моніторинг», «якість освіти». Наприклад, Ж. Чернякова в статті «Моніторинг якості інтернаціоналізованої освіти: досвід Великої Британії» опирається на визначення категорії «якість освіти», яке визначено в документі «Оцінка якості вищої освіти у Великобританії», у якому під якістю вищої освіти розуміють рівень знань і вмінь, якими студент оволодів під час навчання за умови ефективного викладання, підтримки, оцінювання [6]. А поняття «моніторинг», 3 точки зору дослідниці, є категорією багатоаспектного трактування: «як постійний контроль, ретельне дослідження». Узагалі існуе велика кількість визначень дефініції «моніторинг». Наприклад, А. Пустовіт розглядае iі як «спеціально організоване спостереження за будь-яким процесом і з метою виявдення його відповідності бажаному результату або початковим прогнозам»; В. Горб як «спосіб отримання певної інформації, можливості використання якої залежить від компетентності суб'єкта, у розпорядженні якого вона опинилася»; О. Локшина система збору, опрацювання й поширення інформації про діяльність 
освітньої «системи, що забезпечуе безперервне відстеження за іiі станом і прогноз розвитку»тощо.

Зміст діяльності міжнародних організацій схарактеризувала Ж. Чернякова i, насамперед, агентств із контродю якості вищої освіти у Великій Британії. Нею визначено та розкрито зовнішній і внутрішній моніторинг якості освіти в національній освітній системі країни. Одночасно дослідниця зазначає, що міжнародна організація стандартизації пропонуе перелік інтернаціоналізаційної діяльності, який зареєстрований та включений до моніторингу якості інтернаціоналізованої освіти [6, с. 200]. За нашим переконанням, це положення є важливим тому, що в умовах інтернаціоналізації відбувається об'єднання підходів щодо моніторингу якості освіти, яка визначається на внутрішньому рівні (самооцінку проводить сам навчальний заклад), на зовнішньому рівні (оцінка міжнародних програм); представлена національною акредитацією (оцінка міжнародних програм), міжнародною організацією зі стандартизації (ISO 9000); процедурою якісного аналізу інтернаціоналізації (для отримання інформації про інтернаціоналізаційну діяльність в іноземних закладах IQRP). Останній моніторинг є незалежним і складається з представників, які очолюють університети й коледжі Великої Британії та є відповідадьними за проведення моніторингу щодо визначення стандартів і якості освіти.

Зовнішній моніторинг складається 3 оцінювання навчальних програм вищих навчальних закладів, навчальних програм для аспірантів, підготовки вчителів, програм акредитації, які проводяться професійними, установленими керівними органами.

Внутрішній моніторинг якості освіти проводять фахівці самого навчального закладу з метою підвищення ефективності адміністрування, активізації навчальновиховної діяльності, проведення науково-дослідницької роботи тощо. Ураховуючи, що університети і коледжі Великої Британії є автономними, вони самі відповідають за підтримку освітніх стандартів і якість освіти, які надають.

Таким чином, внутрішній моніторинг якості освіти на інституційному рівні передбачає вивчення таких питань: освітня політика навчального закладу, перегляд й ухвалення програми моніторингу освіти, правила й механізми моніторингу освіти і процеси моніторингу та зворотного зв'язку. Для реалізації цього плану необхідно передбачити такі організаційні моменти: відбір персоналу для проведення моніторингу, оцінювання персоналу, внутрішню перевірку, визначення зовнішніх екзаменаторів для проведення моніторингу [6, с. 201].

Отже, вищі навчальні заклади звертаються до зовнішніх екзаменаторів, які є незалежними й допомагають провести моніторинг якості освіти та визначити міжнародні освітні стандарти в контексті інтернаціоналізації європейського освітнього простору.

Переосмислення традиційної системи оцінювання знань учнів/студентів спостерігається й у Франції - країні, яка, як зазначає О. Пермякова, «здійснює пошук нових форм ефективності діагностики якості освіти відповідно до єдиних європейських стандартів, може бути цікавим і корисним для української освітньої спільноти» [5]. Автор наголошуе на особливостях проведення моніторингу якості навчання з закладах освіти Франції в контексті сучасних міжнародних моніторингових досліджень і підкреслюе, що головне завдання проведення моніторингу в освіті спрямоване на забезпечення іï якості. Освітні департаменти Франції надають великого значення не лише моніторингу якості навчання на національному рівні, а й приділяють значну увагу міжнародним моніторинговим проєктам 3 урахуванням національних надбань французької вищої школи. Це досягається за рахунок певних заходів: професіоналізації університетів 3 відкриттям нових спеціальностей, можливої інтеграції освітнього процесу й наукових досліджень, а головне - підтримки високої якості освіти через удосконалення процедур, механізмів і стимулів системи контродю іiі якості [2, с. 135]. Процеси реформування системи вищої освіти Франції торкнулись структури

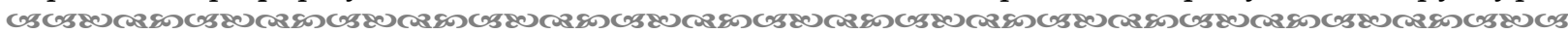
168 
навчальних програм, їхнього змісту й якості надання освітніх послуг, тобто державні структури намагаються змінити підхід 3 прямого контролю сфери вищої освіти на здійснення стратегічного управління. Зокрема, у 2006 році для забезпечення якості освіти було створено урядовий орган AERES, завданням якого є перевірка й оцінювання якості, стратегій, розроблених саме освітянами та дослідниками. Один раз на чотири роки Міністерство укладає з закладами вищої освіти нову угоду тільки після проходження процедури акредитації через AERES. Окрім цього, урядовий орган здійснює комплексне інспектування, що дає змогу виділити критерії вимірювання результатів й оцінювання ефективності діяльності закладів вищої освіти [2, с. 136].

Поширенню в Україні досвіду в галузі освіти Франції сприяють міжнародні конференції, офіційні візити та інші заходи. Один із таких візитів відбувся 26 листопада - 3 грудня 2016 р. в межах проєкту «Навчальні програми професійного зростання». Українська делегація освітян мала можливість зустрітися 3 представниками Міністерства національної освіти, вищої освіти і наукових досліджень, національної генеральної інспекції управління освітою і наукових досліджень, яка забезпечує нагляд та оцінювання в системі управління освітою на всіх рівнях і в усіх сферах, контролюе стан реалізації навчальними закладами державної освітньої політики.

До европейського освітнього простору входить і Румунія, яка є учасником проекту «Імплементація системи забезпечення якості освіти через співробітництво університетубізнесу-уряду в 3ВО» і досягла ступеня «чудової продуктивності» у 8 показниках з 20-ти: ступінь впровадження 1 і 2 університетських циклів, участі студентів у дворівневій системі вищої освіти, розробки зовнішньої системи контродю якості тощо. 30-35 вишів як державних, так і приватних відповідають досить високим стандартам якості освіти. 3 вересня 2009 р. Румунське агентство забезпечення якості вищої освіти є членом Європейської асоціації із забезпечення якості вищої освіти [4, с. 362-363].

Цікавим для України також є досвід вирішення проблеми якості вищої освіти країн Балтії, де освіта відзначається високою якістю, а заклади вищої освіти є одними 3 кращих у Європі. Вони першими 3 пострадянських країн підписади Болонську декларацію й розпочали реформування змісту і структури вищої освіти. Оцінка iï якості, згідно з декларацією про співпрацю в галузі гарантії якості вищої освіти, здійснюється міжнародними комісіями, до складу яких вкдючені зарубіжні експерти 3 країн СС (не менше 2-х, виключаючи участь представників Міністерства, ректорів та місцевої влади). У країнах Балтії переважають експертні форми оцінки якості освітніх програм, увага до внутрішньоуніверситетської освітньої політики й системи контродю якості (відвідування, бесіди, різноманітні форми контродю тощо). Подібність в оцінці якості освіти в цих країнах не заважає їм мати й індивідуальні особливості. Зокрема, у Естонії в 2009 р. було створено Естонське агентство $з$ якості вищої освіти, яке відповідає за оцінку вищої і професійної освіти; у Латвії 1994 р. заснований Центр оцінки якості вищої освіти, що проводить реєстр програм вищої освіти й надає інформацію про 3ВО; у Литві за оцінку якості освіти відповідає Центр з оцінки якості вищої освіти, створений у 1995 р. (реорганізований у державну установу управління 2002 р.). Також особливостями є те, що, наприклад, в Естонії не є обов'язковим ліцензування для державних 3ВО; при оцінюванні діяльності закладу вищої освіти якість знань студентів не перевіряється (відбуваються тільки бесіди) [3].

Висновки. Аналіз публікацій вітчизняних науковців 3 проблем моніторингу якості вищої освіти в зарубіжних країнах засвідчуе, що українським органам освіти варто взяти до уваги політику провідних європейських країн щодо вимірювання стандартів якісної освіти взагалі і вищої, зокрема, у контексті міжнародних вимог. Водночас важдиво, щоб, ураховуючи в Україні досвід європейської вищої школи моніторингу якості освіти в контексті сучасних евроінтеграційних процесів, зберегти націонадьну ідентичність. Це може складати перспективу подальшого наукового пошуку. 


\section{Список використаних джерел:}

1. Закон України «Про вищу освіту» № 1556-VII від 1 липня 2014 p. URL : https://vnz.org.ua/zakonodavstvo/111-zakon-ukrainy-pro-vyschu-osvitu.

2. Дурдас А. Вища освіта Франції в контексті сучасних євроінтеграційних процесів. Неперервна професійна освіта: теорія і практика. Серія: Педагогічні науки. 2017. Вип. № 1-2 (5051). С. 132-137.

3. Конограй В. В. Система оцінки якості вищої освіти в країнах Балтії: порівняльний аналіз. Педагогічні науки: теорія історія, інноваційні технології. 2015. № 10. С. 345-355.

4. Никифоренко Н. О. Румунський досвід забезпечення якості вищої освіти згідно стандартів ESG. Стратегічний потенціал державного та територіального розвитку: матеріали II Міжнародної наук.-практ. конф., м. Маріуполь, 4-5 жовт. 2018. Маріуполь, 2018. С. 362-364.

5. Пермякова О. Г. Моніторинг якості освіти Франції у контексті міжнародних досліджень. URL : www.nbuv.gov.ua/portal/soc gum/pspo/2005 8 1/.../permyakova.pdf

6. Чернякова Ж. Ю. Моніторинг якості інтернаціоналізованої освіти: досвід Великої Британії. Наукові записки НДУ ім. М. Гоголя. Психолого-педагогічні науки. 2013. № 3. С. 196-201.

\section{References:}

1. Law of Ukraine On Higher Education from July 1 2014, No 1556-VII. Retrieved from https://vnz.org.ua/zakonodavstvo/111-zakon-ukrainy-pro-vyschu-osvitu [in Ukrainian].

2. Durdas, A. (2017). Vysha osvita Frantsii v kontekste suchasnykh yevrointehratsiinykh protsesiv [French higher education in the context of modern European integration processes]. Neperervna osvita: teoriia i praktyka. Seriia: Pedagogichni nayky, 1-2 (5051), 132-137 [in Ukrainian].

3. Konohrai, V. V. (2015). Systema otsinky yakosti vyshchoi osvity $\mathrm{v}$ krainakh Baltii: porivnialnyi analiz [The quality assessment system of higher education in the Baltic States: a comparative analysis]. Pedagichni nauky: teoriia, innovatsiyni tekhnolohii, 10, 345-355 [in Ukrainian].

4. Nykyforenko, N. O. (2018). Rumunskyi dosvid zabezpechennia yakosti vyshchoi osvity zhidno standartiv ESG [Romanian experience in quality assurance in higher education according to ESG standards], Stratehichnyi potentsial derzhavnoho ta terytorialnoho rozvytku, materialy II Mizhnarodnoi naykovo-praktychnoi konferetsii [Strategic potential of state and territorial development, Proceedings of the II International Scientific and Practical Conference]. Mariupol [in Ukrainian].

5. Permiakova, O. H. Monitorynh yakosti osvity Frantsii u konteksti mizhnarodnukh doslidzhen [Monitoring the quality of education in France in the context of international research]. Retrieved from www.nbuv.gov.ua/portal/soc gum/pspo/2005 8 1/.../permyakova.pdf [in Ukrainian].

6. Cherniakova, Zh. Yu. (2013). Monitorung yakosti internatsionalizovanoi osvity:dosvid Velykoi Brytanii [Monitoring the quality of internationalized education: the experience of the United Kingdom]. Naukovi zapysky NDU im.M.Hoholia. Psykholoho-pedahohichni nauky, 3, 196-201 [in Ukrainian].

Zavgorodnia T. K., orcid.org/0000-0001-9097-5714

\section{FOREIGN EXPERIENCE OF MONITORING OF THE QUALITY} OF HIGHER EDUCATION IN THE RESEARCH OF DOMESTIC SCIENTISTS

In the article the importance for present time of providing of the quality of education in general and higher in particular is reasonable, the results of researches of the Ukrainian scientists of the system of monitoring of the quality of the higher education in foreign countries in the context of transformation of society and reformation of Ukrainian establishments of the higher education are presented. Scientific work of foreign researchers of the problems of generalization of the experience of the educational monitoring of the quality of the higher education in the different types of educational establishments and activity of the specially created international organizations and, first of all, agencies from control of the quality of education is analysed. Activity of the different institutes of control is reflected after the quality of education in establishments of the higher education of Ukraine. It is well-proven that the primary objective of activity of the last is determination of optimal ways of upgrading of educational process and acceptance of corresponding administrative decisions. Different approaches to the essence of the concepts "internationalization of education", "the quality of education", "monitoring", theoretical, methodological and organizational aspects of monitoring the quality of higher education, 
which are represented by Ukrainian and foreign scientists, are exposed. It is established that in the context of internationalization of education there is a combination of approaches to monitoring the quality of education, which is determined internally, at the external level, represented by national accreditation and international organization on standardization; procedure for qualitative analysis of internationalization.

The key role of monitoring in improving the quality of education has been identified. It is proved that the quality of higher education is recognized as a priority for the development of the modern information society, the main strategy of educational policy of developed countries. It is substantiated that the monitoring of the quality of education is aimed at ensuring compliance with the relevant standards of education in the activities of educational institutions and the provision of high quality educational services to society.

Key words: monitoring, the quality of education, higher education, educational space, research, experience, international standards, system of public management of quality of education.

Дата надходження статті: 17.01.2020 p. Рецензент: доктор педагогічних наук, професор Стражнікова I. В.

У,К [378.07:005.336.4]: 351.851(0)(045)

DOI https://doi.org/10.37915/pa.vi45.67

Шоробура I. M. ${ }^{*}$,

orcid.org/0000-0003-3728-7968

\section{ЗАРУБІЖНИЙ ДОСВІД ДЕРЖАВНО-ГРОМАДСЬКОГО УПРАВЯІННЯ ОСВІТОЮ}

Розглянуто зарубіжний досвід державно-громадського управління освітою як основний напрям демократизації освітньої політики. Функціювання державно-громадської системи управління освітою не можливе без добровільної активної участі в управлінні представників громадськості: громадських лідерів, зокрема, депутатів, членів освітніх громадських організацій, бізнесменів, батьків, педагогів. Сьогодні в Украйні при органах влади створено громадські ради, колегїі, представників громадськості уведено до складу колегій.

Вивчення світових тенденцій та особливостей розбудови освіти, модернізація управлінських механізмів має важливе значення для реформування освіти Украйни, дає основу для прогнозування й реального відродження національної освіти, системного управління нею танаближення до європейських стандартів. Вивчення досвіду європейських крайн викликане їхнім теоретичним та практичним здобутком у изій сфері діяльності $і$ є пізнавальним для розбудови державно-громадської системи управління.

у більшості країн світу управління освітою здійснюеться на трьох рівнях: центральному або верхньому, регіональному, місцевому. Центральний переважае в таких європейських державах, як Греціія, Ірландія, Ісландія, Італія, Норвегія, Португахія, Франція та ін. У країнах з федеральним державним устроєм (Німеччина, США, Канада, Швейцарія та ін.) освітою управляють суб'єкти федерації, які, до речі, є цеентральним рівнем, а федерального в деяких країнах взагалі не існуе. Подаються приклади державно-громадського управління в Даніі, Аитві, Аюксембурзі, Польщі, Словаччині, Туреччині, Фінляндї та інших краінах.

Вивчення зарубіжного досвіду є пізнавальним для розбудови Україною державногромадської системи управління освітою. Подальші розвідки вбачаємо в питанні залучення інституцій громадянського суспільства.

Ключові слова: освіта, управління, державно-громадське управління, зарубіжний досвід.

*C Шоробура I. M.

जos 